\title{
Iranian EFL Learners' Vocabulary Development through Wikipedia
}

\author{
Reza Khany ${ }^{1} \&$ Fereshteh Khosravian ${ }^{1}$ \\ ${ }^{1}$ Department of English Language and Literature, Ilam University, Iran \\ Correspondence: Reza Khany, Department of English Language and Literature, Ilam University, PO Box 516, \\ Ilam 69315, Iran. Tel: 98-918-341-1306. E-mail: khani_reza@yahoo.com
}

Received: March 25, 2014 Accepted: May 26, 2014 Online Published: June 13, 2014

doi:10.5539/elt.v7n7p57 URL: http://dx.doi.org/10.5539/elt.v7n7p57

\begin{abstract}
Language teaching has passed through a long way in search of a remedy for language learners and teachers. Countless theories, approaches, and methods have been recommended. With all these, however, more inclusive L2 theories and models ought to be considered to come up with real classroom practices. One of such crucial practices is authenticity, being straightforwardly found in web-based materials in general and Wikipedia texts and tasks in particular. In the same line and based on sound theoretical underpinnings, the place of Wikipedia is investigated in this study as a prospective tool to teach and learn a major language component with practical procedures i.e. vocabulary knowledge. To this end, 36 intermediate Iranian EFL students assigned to two control and experimental groups took part in the study. The results of the tests administered divulged that the learners in the Wikipedia group surpassed those of the control group. Hence, Wikipedia is considered as an encouraging authentic resource to assist EFL learners in improving their vocabulary knowledge. Implications of present findings and suggestions for further research are discussed.
\end{abstract}

Keywords: authenticity, EFL/ESL learners, language teaching, vocabulary knowledge, wikipedia

\section{Introduction}

Today, there is an agreement that prosperous language education relies greatly on comprehensive tenets of teaching and learning (Brown, 2001; Kumaravadivelu, 2003). These tenets ought to be upheld to develop any task of teaching or learning (Bachman, 1991). In this regard, language specialists are expected to seek those texts and tasks having such requirements. Of these requirements is authenticity (Widdowson, 1979, 1990; Bachman, 1990, 1991; Morrow, 1991; Wood, 1993; Bachman \& Palmer, 1996; Douglas, 1997; Lewkowicz, 1997; Cumming \& Maxewell, 1999). On the other hand, twenty first century technologies assist educated teachers to employ modern tools in their classrooms (International Reading Association, 2009). Though the generality of Information and Communication Technology (ICT) is crystal clear in nearly all facets of twenty first century life, it is not obvious yet how teachers can efficaciously integrate technology into education in general and vocabulary teaching in particular (Dalton \& Grisham, 2011). The methods of vocabulary learning are somewhat mysterious; nevertheless, the good news is that words are not suddenly acquired, especially not for adult L2 learners (Schmitt, 2000). Schmitt (op.cit.) states that vocabularies are progressively learned during a time period from multiple disclosures that are revealing in many ways. To improve academic achievement for success in intermediate or advanced education levels, students' vocabulary enhancement is an area of crucial requirement (Biancarosa \& Snow, 2006; Graves \& Watts-Taffe, 2008). Besides, vocabulary development is an area where teachers are asking for guidance on instructional approaches, strategies, and materials (Berne \& Blachowicz, 2008).

Among a number of tools recommended for integration in language teaching such as Moodle, WizIQ, Podcasts, vodcasts, emails, wikis, etc., wikis has gained much attention as an aid in language education. The Online Oxford English Dictionary defines wiki as "a digital writing space which allows users to freely create, edit, delete, and/or modify webpage content collectively". Recently, Wikipedia, a free, web-based, collaborative, multilingual encyclopedia project supported by the non-profit Wikipedia Foundation, has become known as an available wiki. Wikipedia can be generally considered as a promising tool to expedite social constructivist learning processes (Bruns \& Humphreys, 2005; Ruth \& Houghton, 2009; Khany \& Khosravian, 2013). It can also challenge traditional pedagogical hypotheses regarding teaching some skills or sub-skills of language (Forte \& Bruckman, 2006; Lundin, 2008; Mak \& Coniam, 2008a, 2008b). Bearing all these in mind, it may be surmised that the studies on Wikipedia and language pedagogy is in its infancy. As a result, the current study concentrated 
upon 1. Justifying the place of Wikipedia as a prospective tool to teach and learn language, 2. Displaying the possible procedures in which Wikipedia may develop Iranian EFL learners' vocabulary knowledge. In what follows, the prospects of Wikipedia for language teaching and learning are presented in terms of a. Linguistic considerations, b. Psychological and psycholinguistic considerations, and c. Pedagogical considerations including individual differences as well as learner autonomy.

\subsection{Prospects of Wikipedia for Language Pedagogy (Content, Format, Features)}

Wikipedia enjoys a number of features at different levels; on the face of its design, the tools it offers, and the potential it has in terms of linguistics, psychology, and pedagogy. Wikipedia software has a plethora of features grown out of the needs of the users and the ideas of the developers. The main Wikipedia software currently has the following functions, mentioning only a few: Every user can add articles to their watch list and edit them; Users can upload and embed any file type; Users can see links to articles below a certain size rendered in a different color; Users can enable an option that allows them to edit articles by double clicking or to edit individual sections of an article, separated by headlines, instead of loading the entire article; There are some special report pages including new pages, ancient pages, list of images, list of users, site statistics, orphaned articles, orphaned images, popular articles, most wanted articles, short articles, long articles, and a list of all pages by title; It is supported for auto-numbering headings in an article, and/or generating a table of contents for long articles, for linking to individual sections of an article, and also encompassing inter-language link, only if multiple wikis are set up. Most of these features seem convenient for the application in EFL/ESL classrooms, in terms of linguistic, psycholinguistic, psychological, and pedagogical considerations and can be tailor-made to the needs of individual language learners.

\subsection{Application of Wikipedia in EFL/ESL Classrooms}

Of good reasons to employ Wikipedia in language teaching classrooms are; it is quick and simple to use and allows collaboration, independently of time and space, via easily accessible online spaces. Moreover, it allows students to be actively engaged in reading and writing: correcting, editing, and up-dating. It also provides students the skills of collaboration alongside language skills. In addition, Wikipedia can support teachers in their classroom management. It is mostly suitable for some tasks and pedagogies concerned with intermediate to advanced students more than for beginners who have limited language skills. Nevertheless, even students who have limited language skills can use Wikipedia in a collaborative way. They can collect vocabulary in the L2; write language learning tips in the L1; collect links to interesting L2 websites; and comment on them in the L1. Wikipedia naturally offers authentic reading practice, as a receptive skill to gain vocabulary (Nagy \& Herman, 1985; Cunningham \& Stanovich, 2001; Baumann \& Kame'enui, 2004; Pearson, Hiebert, \& Kamil, 2007) as well as text comprehension (Beck, McKeown, \& Kucan, 2008). By the same token, studies show those students who possess a considerable amount of vocabulary can indirectly acquire many more words through reading than from teaching, though it sounds necessary to instruct vocabulary directly (Nagy \& Herman, 1985; Cunningham \& Stanovich, 2001). As a whole, Wikipedia seems appropriate for group work, tele collaboration, students working on their own or independently, supporting motivation, group cohesion, reflective learning, and "ownership" of content.

\subsubsection{Linguistic Considerations}

The development of studies on the structure and scope of language has led to a number of models proposed in the field. One such model which seems to have attracted a lot of attention is communicative language ability (CLA) proposed by Bachman (1990). CLA consists of language competence, strategic competence, and psycho physiological mechanisms. Language competence includes organizational competence, which consists of grammatical and textual competence, and pragmatic competence, which consists of illocutionary and sociolinguistic competence. Strategic competence is seen as the capacity relating language competence, or knowledge of language, to the language user's knowledge of structures and the features of the context in which communication takes place. Strategic competence performs assessment, planning, and execution functions in determining the most effective means of achieving a communicative goal. Psycho physiological mechanisms involved in language use characterize the channel (auditory, visual) and mode (receptive, productive) in which competence is implemented. Now, over the last century, the concern of many language educators or pedagogues have been to design and develop materials which best can tap the linguistic features embodied in linguistic theories recommended in the above model. A cursory look at the features of texts and tasks offered by Wikipedia demonstrates that much of such linguistic demands can be tapped by the materials proposed by the given tool. Indeed, if a learner tries to process a text on Wikipedia, $\mathrm{s} / \mathrm{he}$ has to be equipped with the knowledge of language embodied in the CLA model. 


\subsubsection{Psychological and Psycholinguistic Considerations}

Psychologically, anxiety, competitiveness and shock in a new, perhaps uncontrollable situation can make the language-learning situation problematic and stressful. Besides, anxiety and stress are prevalent both in classroom and individual learning contexts (Bailey, 1983; Mackey \& Gass, 2005; Gass \& Mackey, 2007). One important point Bailey (1983) makes is that anxiety depends on the situation in which learners find themselves. Too often, studies assume some uniform, global relationship between language-learning success and a motivating factor. Online social networking is a type of virtual communication allowing people to connect one another. This concept arises from a basic need of human beings to stay together in groups, forming a community. Social networking sites, email, instant messaging, video- and photo- sharing sites and comment posting are all tools that help people to communicate and socialize with each other (Mooney, 2009). Concerning vocabulary learning, as illustrated in Figure 1, Goodridge (2010) proposed a scheme of how memory operates.

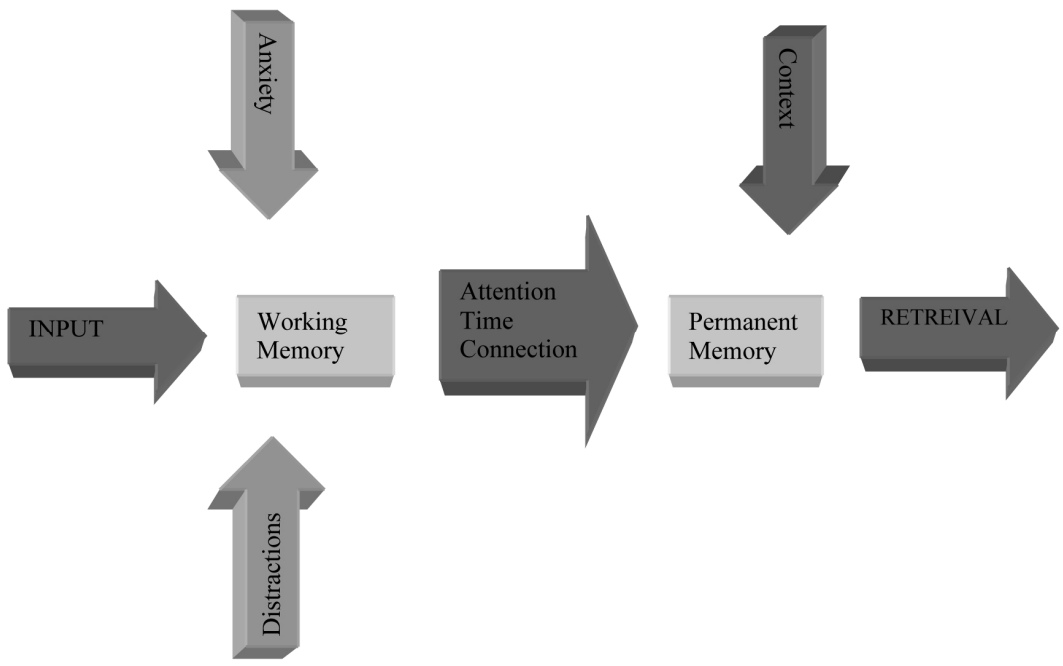

Figure 1. Function of memory (Goodridge, 2010, p. 1)

According to Figure 1, Goodridge (2010) describes when sensory input received; it is first kept in the working memory, keeping a roughly permanent amount of items, that is, around seven for almost all people at a point in time, even though this is reduced by anxiety. Besides, distractions can block the "slots" and consequently leave even less space to work with sensory input. The working memory can manage to analyze the received information and as a result they can be stored in the permanent memory through this activity. When the recent information is linked to the old one, the new one can be integrated into memory.

Once a new vocabulary is learned, an association is made between form and meaning. This association may take the form of an L1 equivalent, L2 synonym or definition, visual image, feeling, sound, emotion, a certain situation or context, or a combination of these. The greater the amount of associations is made, the more likely they are remembered by the learners. After the new word is stored in the permanent memory, it is required to be regained for use. This regain or retrieval is commonly activated via linguistic or situational context. Wikipedia texts are recommended for such linguistic or situational context for the learners to meet the words on several occasions in their learning so as to improve their knowledge and use of words in the foreign or second language (Cameron, 2001). In this regard, Thornbury (2002) states, "To ensure long-term recall and retention, new knowledge should be integrated to old/existing knowledge, i.e. they need to be placed into working memory e.g. being compared, combined, matched, sorted, visualized and re-shuffled..." (p. 45).

\subsubsection{Pedagogical Considerations}

Along with linguistic, psychological, and psycholinguistic considerations, pedagogical considerations should also be observed in the inclusion of any new venture in education. Today, there has been a growing interest in the study of the integration of pedagogy and e-learning (Bradley \& Oliver, 2002; Lakkala, Lallimo, \& Hakkarainen, 2005; Moreno \& Flowerday, 2006; Blay \& Ireson, 2009; Granic, Mifsud, \& Cukusic, 2009; Archambault \& Barnett, 2010; Seale \& Cooper, 2010; Toki \& Pange, 2010; Jia, Chen, Ding, \& Ruan, 2012; Khany \& Khosravian, 2013). ICT has recently gained increasing notice across a wide range of fields. Among the tools offered by ICT, Wikipedia has been increasingly noticed in the cyberspace community. Recently, educators have realized the 
potentials of this collaborative tool for teaching and learning second and foreign languages.

Wikis, especially Wikipedia, have demonstrated enormous potentials to be used in the fields of TEFL, Teaching English as a Foreign Language, and TESL, Teaching English as a Second Language, even though they are not originally intended to be used in education. One of the fields which are embracing the application of these tools is teaching and learning second and foreign language vocabulary. Graves (2006) proclaims that teaching vocabulary should a. supply students with information encompassing context and meaning of the word, $b$. formulate education to engage students and permit adequate time to learn the word, c. ensure students have several disclosures to the words through practice and review, and d. make a conversation about the words. To fulfill this goal, Wikipedia can assist teaching second and foreign language reading (Warschauer, 2010) to improve learners' vocabulary knowledge (Chastain, 1988; Trusty, 2010). Hence, in both reading and vocabulary classes, teachers can utilize these user-friendly tools to provide students with supplementary materials and links for self-study.

Fries (1945, cited in Richards and Renandya, 2002) states that since most of the vocabulary items have several meaning; they can't be learnt in isolation. Nunan (1991) suggests that "When teaching new vocabulary, we should begin by teaching the new item in context, but at a later stage learners should be given the opportunity of dealing with the words out of context" (p. 122). Ellis (1997) states that when students see the words in a piece of discourse they can understand better, thus allowing for more apparent grammatical pattering. Then, an e-learning system design such as Wikipedia, based on selected pedagogical model, enables teachers to make use of the learning resources in a form which is appropriate to the learning goals and the particular learning style of the student (Granic, Mifsud, and Cukusic, 2009).

\subsubsection{Individual Differences}

Individual differences are acknowledged in second language acquisition in general and vocabulary learning in particular (Knopik \& DeFries, 1998; Ehrman, Leaver, \& Oxford, 2003; Perfetti, Wlotko, \& Hart, 2005; Rubin, Katznelson, \& Perpignan, 2005; Sparks, Humbach, \& Javorsky, 2008; Golestani \& Zatorre, 2009; McMurray, Samelson, Lee, \& Tomblin, 2010; D. Luque, J. Luque, \& Lopez-Zamora, 2011). Expert teachers with flexible but clear syllabi can most systematically provide for the individual differences among their students. And just as students vary, so do teachers: in motivation, in overall aptitude, in self-efficacy as teachers, in teaching/learning style, and in preferred strategies. To alleviate the problem, Wikipedia offers texts and tasks fitting with the needs of different language learners. It is in accord with the practice of constructivist teaching and learning.

Kyriacou (2001) emphasizes that “... Activities must elicit and sustain pupils attention, interest and motivation" (p. 23). To directly teach word and vocabulary knowledge strategies or to expand learners' amount of reading, an essential principle is promoting a vigorous interest in vocabularies via learner manifestation and involvement in a learning group to enjoy trifling with vocabularies, to create individual interests and curriculum needs, as well as to stress self-efficacy in vocabulary learning (Beck et al., 2008; Graves \& Watts-Taffe, 2008). Basically, if it is believed that students learn better by actively participating in the learning process, generating their own "theories" about how language works, and practicing language in collaboration with peers, Wikipedia is a tool teachers should not neglect.

Wikipedia supports this kind of collaborative learning, enabling users to develop their own rough version of a text which can then be updated and edited by others. Reading and writing become a collaborative process, and every contributor becomes at once a critic of other entries, an author or co-author and a reader. Checking, correcting, and up-dating the Wikipedia entries can be a potentially valuable way of learning to read and write in a foreign language through peers' help and support, rather than solely the teacher's, and also with a ready audience. Considerable differences in second language attainment, individual learners' experience, and texts variation of Wikipedia can enable students to develop their own meaningful representations of knowledge.

\subsubsection{Learner Autonomy}

Holec (1981) defined learner autonomy as the "ability to take charge of one's own learning". Many studies highlight the importance of learner autonomy in the development of language skills (e.g., Hurd, Beaven, \& Ortega, 2001; Figura \& Jarvis, 2007; Zhou, Ma, \& Deci, 2009; Ciani, Middleton, Summers, \& Sheldon, 2010). There is a considerable connection between cognitive depth along with retention, allowing teachers to encourage learners make decisions about the new language they are learning (Craik \& Lockhart, 1972, cited in Goodridge, 2010). If teachers encourage learners to select which words from a text they would like to learn, retention is additionally enhanced. It is also verified by Atkinson (1972, cited in Goodridge, 2010), who advocates that learners who make a choice of which vocabulary to learn accomplish $50 \%$ better in vocabulary retaining tests than when they must study word lists set for them. Once learners are engaged in activities that make them think 
and decide on the words they're going to learn, they are enabled to recall the words more efficiently. Hence, learners require dealing with a variety of activities to stimulate their thinking and to elevate their decision making. Wikipedia as an authentic source with a bunch of varied texts can present the learners such an opportunity to select any kind of texts based on their own interest, thereby fostering an atmosphere for language learners' autonomy. Having all these in mind, and in order to realize how such theoretical potentials can be tested, the second section of the study reports on the application of the given tool to see if Iranian EFL learners' vocabulary knowledge can be improved, utilizing Wikipedia texts.

\section{Method}

\subsection{Participants}

Thirty six intermediate English language learners, all female, ranging in age from 16 to 22, participated in the study. They randomly were assigned to two equal groups of experimental and control (18 students in each group).They studied English in a language institute in Ilam, a city in western Iran. They were selected out of 56 students based upon their performance from an Oxford Placement Test (Allan, 1999), administered as a placement test.

\subsection{Instruments}

Two tests, namely Oxford Placement Test (Allan, 1999) and a researcher-teacher-made test were used as the pre and posttest respectively. The posttest, a 30-item vocabulary test, was designed based on the vocabularies drawn from Wikipedia pages taught throughout the instruction sessions. All the items were in multiple-choice format.

\subsection{Procedure, Data Collection and Analysis}

A semester of three months was taken to conduct the research. The pretest, as the placement test, was administered at the beginning of the semester to divide the students into two homogeneous groups of control and experimental. Afterwards, throughout twelve instruction sessions, Wikipedia online and traditional texts were presented to learners in experimental and control groups. To fairly compare the groups and to emphasize the specifications of Wikipedia, students in the control group were exposed to Wikipedia handouts, provided by the researcher. With regard to experimental group instruction, it is noteworthy that those Wikipedia pages including most of the features of Wikipedia such as hyperlinks, hypertexts, podcasts, video casts, etc. were selected on the basis of learners' interest and options. At the end of the semester, the posttest was administered to both groups. Eventually, to see if those learners in experimental Wikipedia group had made any advancement in their vocabulary knowledge, the data were analyzed via some inferential statistics.

\section{Results}

In response to the enquiry; can Iranian EFL learners' vocabulary knowledge be improved through Wikipedia texts? Independent Samples Test using SPSS software, version 16 was run for statistical analysis. Initially, to find out whether the groups were homogeneous, mean, standard deviation, and standard error mean for pretest grades of the groups were computed and compared through descriptive statistics (See Table1).

Table 1. Descriptive statistics for pretest grades

\begin{tabular}{lllll}
\hline Group & $\mathrm{N}$ & Mean & Std. Deviation & Std. Error Mean \\
\hline Traditional & 18 & 14.22 & 2.88 & .67 \\
Wikipedia & 18 & 13.72 & 2.98 & .70 \\
\hline
\end{tabular}

The results of Independent Samples Test are revealed in Table 2.

Table 2. Independent samples test results for the level of participation

\begin{tabular}{lllllll}
\hline & \multicolumn{5}{c}{ T-test for equality of means } \\
\hline${ }^{*} \mathrm{P}<.05$ & $\mathrm{t}$ & $\mathrm{df}$ & $\begin{array}{l}\text { Sig. } \\
(2 \text {-tailed })\end{array}$ & $\begin{array}{l}\text { Mean } \\
\text { Difference }\end{array}$ & Siffere & Difference \\
Grades (Equal variances not assumed) & .512 & 33.96 & $.612 *$ & .50 & .97 \\
\hline
\end{tabular}


As illustrated in Table 2, the mean difference between Traditional and Wikipedia groups is not substantial. Additionally, the insignificancy of .612 reveals that the groups are almost homogeneous. Then, further analysis can be accomplished to check the significance between the pertinent groups in regard to their final performance. Table 3 illustrates the descriptive statistics for grades of the posttest.

Table 3. Descriptive statistics for final grades

\begin{tabular}{lllll}
\hline Group & $\mathrm{N}$ & Mean & Std. Deviation & Std. Error Mean \\
\hline Traditional & 18 & 13.38 & 1.91 & .45 \\
Wikipedia & 18 & 17.00 & 1.78 & .42 \\
\hline
\end{tabular}

As divulged in the preceding table, there is a considerable difference in the final performance of the groups, Traditional and Wikipedia. Finally, to examine the significance of the observed difference between the groups' final scores, as aforementioned, Independent Samples Test was administered. The results are demonstrated in Table 4.

Table 4. Independent samples test results for the level of participation

\begin{tabular}{|c|c|c|c|c|c|}
\hline \multirow[b]{2}{*}{ Difference } & \multirow[b]{2}{*}{$\mathrm{t}$} & \multicolumn{4}{|c|}{ T-test for equality of means } \\
\hline & & df & $\begin{array}{l}\text { Sig. } \\
\text { (2-tailed) }\end{array}$ & $\begin{array}{l}\text { Mean } \\
\text { Difference }\end{array}$ & $\begin{array}{l}\text { Std. Error } \\
\text { Difference }\end{array}$ \\
\hline Grades (Equal variances not assumed) & -5.85 & 33.82 & $.000^{*}$ & -3.61 & .61 \\
\hline
\end{tabular}

The significance of .000 confirms the significant difference between Traditional and Wikipedia groups' performance. In other words, it denotes that students in the Wikipedia class had a performance that was superior to those in the Traditional class. Figure 2 apparently illustrates the difference.

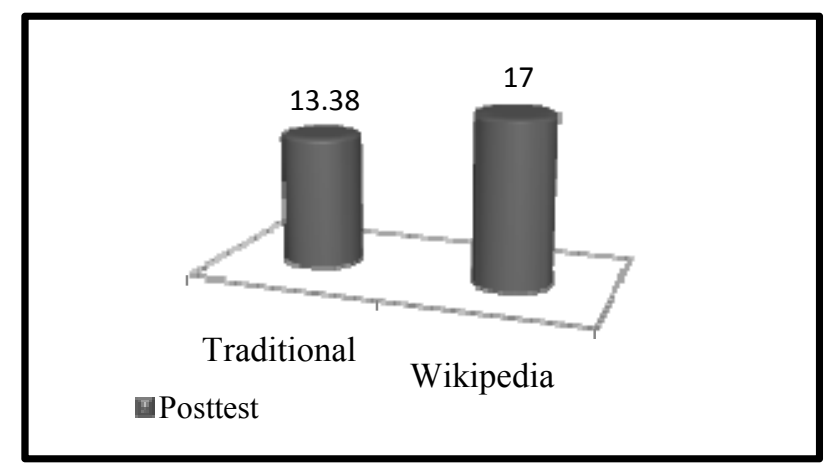

Figure 2. The mean difference of posttest between traditional and wikipedia groups

\section{Discussion and Conclusion}

Having reviewed the pertinent considerations in section one, the second goal of the present study was to investigate the role of Wikipedia pages or texts in Iranian EFL learners' vocabulary development. In so doing, learners in the experimental group were exposed to those online English Wikipedia texts having most of the specifications of Wikipedia pages including hyperlink, hypertext, etc. while learners in the control group used only Wikipedia printed texts. During teaching sessions, for the Wikipedia group, the desired words were searched in Wikipedia main page by learners, a word for each session. For instance, "fruit" was chosen for a session, numerous words and concepts relating to fruit such as different types of fruit, fruit development, its production, and so many other words in regard to the vocabulary were found. 
In another session, "sport" and its related vocabularies were taught. Finding the word in Wikipedia, different types of sport, its etymology and the history of sport through some pictures (See Figure 3), available via hyperlinks and hypertexts, were seen to make the words more meaningful to learn. This method of education seems to be in line with what Anderson and Ausubel contended, that meaning is not an implicit response, but a "clearly articulated and precisely differentiated conscious experience emerging when potentially meaningful signs, symbols, concepts, or propositions are related to and incorporated within a given individual's cognitive structure on a non arbitrary and substantive basis" (1965, p. 8 cited in Brown, 2000, p. 83). Moreover, it is in contrast to what Ausubel defined as rote learning, the process of acquiring material as "discrete and relatively isolated entities that are relatable to cognitive structure only in an arbitrary and verbatim fashion, not permitting the establishment of [meaningful] relationships" (1968, p. 108 cited in Brown, 2000, p. 83). Finally, those learners who preferred to learn more words about a specific topic could go to two other links, further reading and external links, at the end of the page.
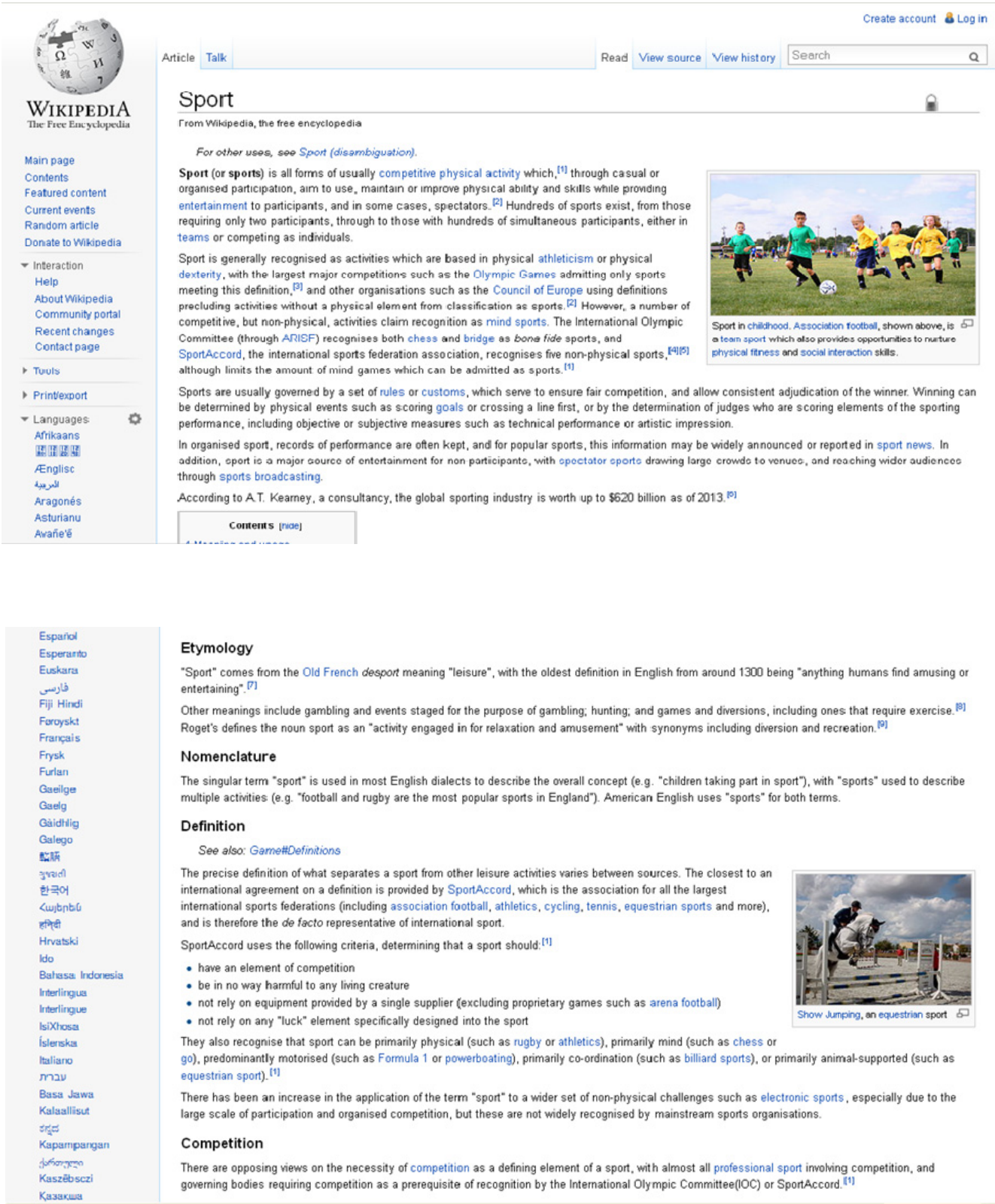

Figure 3. Pictures of wikipedia pages about the related topic "sport" 
After the instruction period and the posttest administration, the scores were put into analysis. Considering the results, those learners participating in Wikipedia classroom outperformed those who took part in the traditional classroom. In other words, the learners in Wikipedia Class reported higher motivation, sense of communal work, collaboration, and pleasure and less confusion than those in the Traditional Class. The findings were in accordance with Khany and Khosravian's (2013) position on reading comprehension improvement, using Wikipedia pages.

Besides, as another e-learning tool, Jia, Chen, Ding and Ruan (2012) found that the integration of the open source course management system Module into the ordinary English instruction can improve the students' performance in vocabulary acquisition and in ordinary tests. Again, akin to Khany and Khosravian's (2013) outcomes, the present results can be ascribed to the flexibility, ease of use and collaborative features of Wikipedia which promote higher motivation and participation, leading to superior learning and performance. The application of the vocabulary online learning was technically not a difficult task for the students, but easily accepted by them, although it was the first time for almost all of them to participate in such a kind of learning. This conclusion was arrived at from the statistical analysis of the students' survey.

With what was earlier discussed on the features of Wikipedia and its potentials for language classroom use, the use of the given tool from a pedagogical point of view seems to be justified. The availability of Wikipedia texts may be used to encourage active learning, but the appropriate management of this pedagogical tool may represent a challenge for teachers and students, like the ones investigated, who are confronted with a new technology and are still learning how to explore the potentials of information technology for teaching/learning. There are some possible pedagogical implications for the effective integration of Wikipedia texts in the EFL/ESL classroom. Teachers could and should let the learners select the words they would like to learn. They can help learners to choose the lexes relating to their lives and experiences through a variety of contexts, various suitable learning styles and with different interests.

Special attention should be paid to the meaning of the selected words since it enhances memory retention, cognitive processing, and motivation. Teachers should encourage learners to create connections between vocabularies and make choices of new vocabularies to advance cognitive processing and as a result increase their storage in memory. Finally, teachers should give their learners a chance not only to recall the new words, but also to employ them in a relevant context like those studied from Wikipedia since they would have been equipped enough to understand unfamiliar words through the distinctive features and contextual cues of Wikipedia texts.

Despite all the benefits of applying ICT tools such as Wikipedia in EFL classrooms, there are also some shortcomings. One of the main drawbacks is the unavailability of the required equipment, since there are not always computers accessible to learners which are connected to the Internet and few language institutes are equipped with computers. Even with the advantages and benefits they provide for teachers and learners, the efficiency of these free and user-friendly tools such as Wikipedia depends on the course design, learners' motivation, autonomy, and interest. However, the posed methodology can be employed as a foundation to enhance further studies dealing with social software in various academic systems with different age groups and learning goals.

\section{References}

Allan, D. (1999). Success and failure in community placements for people with intellectual disabilities and challenging behavior: An analysis of key variables. Journal of mental health, 8(3), 307-320.

Archambault, L. M., \& Barnett, J. H. (2010). Revisiting technological pedagogical content knowledge: Exploring the TPACK framework. Computers and education, 55(4), 1656-1662.

Bachman, L. F. (1990). Fundamental considerations in language testing. Oxford: Oxford University Press. http://dx.doi.org/10.1191/02655322031t268xx

Bachman, L. F. (1991). What does language testing have to offer? TESOL Quarterly, 25(4), 671-704.

Bachman, L. F., \& Palmer, A. (1996). Language testing in practice. Oxford: Oxford University Press. http://dx.doi.org/10.1177/136216889900300106

Bailey, K. M. (1983). Competitiveness and anxiety in adult second language learning: Looking at and through the diary studies. In H. W. Seliger, \& M. H. Long (Eds.), Classroom oriented research in second languages. Rowley, MA: Newbury House.

Baumann, J. F., \& Kame'enui, E. J. (Eds.). (2004). Vocabulary instruction: research to practice. New York: 
Guilford.

Beck, I. L., McKeown, M. G., \& Kucan, L. (2008). Creating robust vocabulary: Frequently asked questions and extended examples. New York: Guilford.

Berne, J. I., \& Blachowicz, C. L. Z. (2008). What reading teachers say about vocabulary instruction. The reading teacher, 62(4), 314-323.

Biancarosa, G., \& Snow, C. E. (2006). Reading next: A vision for action and research in middle and high school

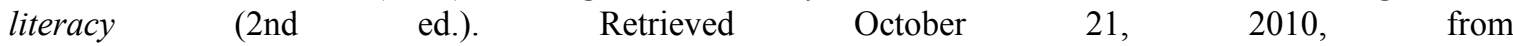
www.all4ed.org/files/archive/publications/ReadingNext/ReadingNext.pdf

Blay, J. A., \& Ireson, J. (2009). Pedagogical beliefs, activity choice and structure, and adult-child interaction in nursery classrooms. Teaching and Teacher Education, 25, 1105-1116. http://dx.doi.org/10.1016/j.tate.2009.03.009

Bradley, C., \& Oliver, M. (2002). The evolution of pedagogic models for work-based learning within a virtual university. Computers and Education, 38(1-3), 37-52. http://dx.doi.org/10.1016/S0360-1315(01)00078-1

Brown, H. D. (2000). Principles of language learning and teaching (4th ed.). White Plains, NY: Longman.

Brown, H. D. (2001). Teaching by principles (2nd ed.). White Plains, NY: Pearson.

Bruns, A., \& Humphreys, S. (2005). Wikis in teaching and assessment: The m/cyclopedia project. In Proceedings of the International Symposium on Wikis (San Diego, USA, 2005). Retrieved from http://www.wikisym.org/ws2005/proceedings/paper-03.pdf

Cameron, L. (2001). Teaching languages to young learners. Cambridge: Cambridge University Press. http://dx.doi.org/10.1017/CBO9780511733109

Chastain, K. (1988). Developing second language skills: Theory and practice (3rd ed.). Orlando, Florida: Harcout Brace Jovanovich.

Ciani, K. D., Middleton, M. J., Summers, J. J., \& Sheldon, K. M. (2010). Buffering against performance classroom goal structures: The importance of autonomy support and classroom community. Contemporary educational psychology, 35, 88-99. http://dx.doi.org/10.1080/01443411003660232

Cumming, J., \& Maxwell, G. (1999). Contextualising authentic assessment. Assessment in education, 6, 177-194.

Cunningham, A. E., \& Stanovich, K. E. (2001). What reading does for the mind. American educator, 22(1-2), $8-15$.

Dalton, B., \& Grisham, D. L. (2011). eVoc strategies: 10 ways to use technology to build vocabulary. The reading teacher, 64(5), 306-317. http://dx.doi.org/10.1598/RT.64.5.1

Douglas, D. (1997). Language for specific purposes testing. Dordrecht: Kluwer Academic.

Ehrman, M. E., Leaver, B. L., \& Oxford, R, L. (2003). A brief overview of individual differences in second language learning. System, 31, 313-330. http://dx.doi.org/10.1016/S0346-251X(03)00045-9

Ellis, R. (1997). SLA research and language teaching. Oxford: Oxford University Press. http://dx.doi.org/10.1017/S027226310022205

Figura, K., \& Jarvis, H. (2007). Computer-based materials: A study of learner autonomy and strategies. System, 35, 448-468. http://dx.doi.org/10.1016/j.system.2007.07.001

Forte, A., \& Bruckman, A. (2006). From Wikipedia to the classroom: Exploring online publication and learning. In S. Barab, K. Hay, \& D. Hickey (Eds.), Proceedings of the 7th international conference on learning sciences (pp. 182-188). Bloomington, Indiana: Indiana University.

Gass, S. M., \& Mackey, A. (2007). Data elicitation for second and foreign language research. Mahwah, NJ: Lawrence Erlbaum Associates.

Golestani, N., \& Zatorre, R. J. (2009). Individual differences in the acquisition of second language phonology. Brain \& language, 109, 55-67. http://dx.doi.org/10.1016/j.bandl.2008.01.005

Goodridge, V. (2010). Memory, mnemonics, and the lexicon. IH Barcelona annual conference, 1-6.

Granic, A., Mifsud, C., \& Cukusic, M. (2009). Design, implementation and validation of a Europe-wide pedagogical framework for e-learning. Computers and education, 53(4), 1052-1081.

Graves, M. F. (2006). The vocabulary book: Learning and instruction. New York: Teachers College Press. 
Graves, M. F., \& Watts-Taffe, S. (2008). For the love of words: Fostering word consciousness in young readers. The reading teacher, 62(3), 185-193. http://dx.doi.org/10.1598/RT.62.3.1

Holec, H. (1981). Autonomy and foreign language learning. Oxford: Pergamon.

Hurd, S., Beaven, T., \& Ortega, A. (2001). Developing autonomy in a distance language learning context: Issues and dilemmas for course writers. System, 29(3), 341-355. http://dx.doi.org/10.1016/S0346-251X(01)00024-0

International Reading Association. (2009). New literacies and 21st-century technologies (position statement). Newark, DE: author. Retrieved September 20, 2010, from www.reading.org/General/AboutIRA/PositionStatements/21 stCenturyLiteracies.aspx

Jia, J., Chen, Y., Ding, Z., \& Ruan, M. (2012). Effects of a vocabulary acquisition and assessment system on students' performance in a blended learning class for English subject. Computers \& education, 58, 63-76. http://dx.doi.org/10.1016/j.compedu.2011.08.002

Khany, R., \& Khosravian, F. (2013). The application of Wikipedia for enhancing Iranian EFL students' reading proficiency (pp. 135-142). Proceeding of the global summit on education 2013 (GSE2013). Kuala Lumpur, Malaysia.

Knopik, V. S., \& DeFries, J. C. (1998). A twin study of gender-influenced individual differences in general cognitive ability. Intelligence, 26(2), 81-89.

Kumaravadivelu, B. (2003). Beyond methods: Macro strategies for language teaching. New Haven, CT: Yale University Press.

Kyriacou, C. (2001). Essential teaching skills. Cheltenham, UK: Nelson Thorne.

Lakkala, M., Lallimo, J., \& Hakkarainen, K. (2005). Teachers' pedagogical designs for technology-supported collective inquiry: A national case study. Computers and education, 45(3), 337-356.

Lewkowicz, J. (1997). Investigating authenticity in language testing (Unpublished PhD dissertation). University of Lancaster.

Lundin, R. (2008). Teaching with wikis: Toward a networked pedagogy. Computers and composition, 25(4), 432-448. http://dx.doi.org/10.1016/j.compcom.2008.06.001

Luque, D., Luque, J. L., \& Lopez-Zamora, M. (2011). Individual differences in pseudo homophony effect relates to auditory categorical perception skills. Learning and individual differences, 21, 210-214.

Mackey, A., \& Gass, S. M. (2005). Second language research: Methodology and design. Mahwah, NJ: Lawrence Erlbaum.

Mak, B., \& Coniam, D. (2008a). Using wikis to enhance and develop writing skills among secondary school students in Hong Kong. System, 36(3), 437-455. http://dx.doi.org/10.1016/j.system.2008.02.004

Mak, B., \& Coniam, D. (2008b). Writing with wikis. Modern English teacher, 17(3), 38-42.

McMurray, B., Samelson, V. M., Lee, S. H., \& Tomblin, J. B., (2010). Individual differences in online spoken word recognition: Implications for SLI. Cognitive psychology, 60(1), 1-39. http://dx.doi.org/10.1016/j.cogpsych.2009.06.003

Mooney, C. (2009). Online social networking. Gale Cengage Learning.

Moreno, R., \& Flowerday, T. (2006). Students' choice of animated pedagogical agents in science learning: A test of the similarity-attraction hypothesis on gender and ethnicity. Contemporary educational psychology, 31(2), 186-207. http://dx.doi.org/10.1016/j.cedpsych.2005.05.002

Morrow, K. (1991). Evaluating communicative tests. In S. Anivan (Ed.), Current developments in language testing (pp. 111-118). Singapore: SEAMEO regional language centre.

Nagy, W., \& Herman, P. A. (1985). Incidental vs. instructional approaches to increasing reading vocabulary. Educational perspectives, 23(1), 16-21.

Nunan, D. (1991). Language teaching methodology. London: Prentice Hall International.

Pearson, P. D., Hiebert, E. H., \& Kamil, M. L. (2007). Vocabulary assessment: What we know and what we need to learn. Reading research quarterly, 42(2), 282-296. http://dx.doi. org/10.1598/RRQ.42.2.4

Perfetti, C. A., Wlotko, E. W., \& Hart, L. A. (2005). Word learning and individual differences in word learning reflected in event-related potentials. Journal of experimental psychology: Learning memory and cognition, 
31(6), 1281-1292.

Richards, J. C., \& Renandya, A. W. (2002). Methodology in language teaching: An anthology of current practice. Cambridge: Cambridge University Press. http://dx.doi.org/10.1017/CBO9780511667190

Rubin, B., Katznelson, H., \& Perpignan, H. (2005). Learning for life: The potential of academic writing courses for individual EFL learners. System, 33, 17-27.

Ruth, A., \& Houghton, L. (2009). The wiki way of learning. Australasian journal of educational technology, 25(2), 135-152.

Schmitt, N. (2000). Vocabulary in language teaching. Cambridge: Cambridge University Press.

Seale, J., \& Cooper, M. (2010). E-learning and accessibility: An exploration of the potential role of generic pedagogical tools. Computers and education, 54(4), 1107-1116. http://dx.doi.org/10.1016/j.compedu.2009.10.017

Sparks, R., Humbach, N., \& Javorsky, J. (2008). Individual and longitudinal differences among high and low-achieving, LD, and ADHD L2 learners. Learning and individual differences, 18, 29-43.

Thornbury, S. (2002). How to teach vocabulary. United Kingdom: Pearson Education Limited.

Toki, E. I., \& Pange, J. (2010). E-learning activities for articulation in speech language therapy and learning for preschool children, Procedia-social and behavioral sciences. Innovation and creativity in education, 2(2), 4274-4278.

Trusty, A. (2010). Augmenting the L1 web for L2 vocabulary learning. Toronto: University of Toronto.

Warschauer, M. (2010). Invited commentary: New tools for teaching writing. Language learning \& technology, 14(1), 3-8.

Widdowson, H. (1979). Explorations in applied linguistics. Oxford: Oxford University Press.

Widdowson, H. (1990). Aspects of language teaching. Oxford: Oxford University Press.

Wood, R. (1993). Assessment and testing. Cambridge: Cambridge University Press.

Zhou, M. M., Ma, W. J., \& Deci, E. (2009). The importance of autonomy for rural Chinese children's motivation for learning. Learning and individual differences, 19, 492-498.

\section{Copyrights}

Copyright for this article is retained by the author(s), with first publication rights granted to the journal.

This is an open-access article distributed under the terms and conditions of the Creative Commons Attribution license (http://creativecommons.org/licenses/by/3.0/). 